\title{
ASSESSMENT ON DIVERSITY AND ABUNDANCE OF ARACEAE IN LIMESTONE AND PYROCLASTICS AREAS IN GUA MUSANG, KELANTAN, MALAYSIA
}

\author{
${ }^{1}$ NIK YUSZRIN BIN YUSOF, ${ }^{1}$ ZULHAZMAN HAMZAH, ${ }^{2}$ FATIMAH KAYAT AND \\ ${ }^{2}$ ZULHISYAM A.K.
}

${ }^{1}$ Department of Earth Science, Faculty of Earth Science, Universiti Malaysia Kelantan Jeli Campus, Locked Bag 100, 16700, Jeli, Kelantan, Malaysia

${ }^{2}$ Faculty of Agro Based Industry, Universiti Malaysia Kelantan Jeli Campus, Locked Bag 100, 16700, Jeli, Kelantan, Malaysia

Corresponding author: anthem_1000@yahoo.com

\begin{abstract}
The study was conducted in Gua Musang, Kelantan, namely; Kuala Koh N 04 $52^{\circ}$ 02.2"/ E 102 26' 33.3" (represents pyroclastics area) and Tanah Puteh N 04 46' 11.9"/ E $101^{\circ}$ 58 '35.5" (represents limestone area). A square plot $(100 \times 100 \mathrm{~m})$ was set-up in both locations for sampling of Araceae. The result shows diversity of Araceae in limestone ( 28 species ha $\left.{ }^{-1}\right)$ is higher as compared to pyroclastics area $\left(21\right.$ species ha $\left.^{-1}\right)$. The most abundant species in limestone are Anadendrum microstachyum, Homalomena griffithii, Rhaphidophora tenuis and Schismatoglottis brevicuspis. In pyroclastics area, the most abundant is $S$. calyptrata followed by, S. scortechinii, S. brevicuspis and A. microstachyum. The common species in both areas was hemiepiphytic $R$. mangayi. The least abundant species in limestone are Amorphophallus sp. and Homalomena Chamaecladon Supergroup. Meanwhile, Scindapsus perakensis, Homalomena Cyrtocladon Supergroup, $H$. pontederiifolia and Aglaonema simplex were counted as least abundant species in pyroclastics area. Geological features, topography (whether on-slope, onridge or edge of stream), and altitude are the most influencing factor on distribution and abundance of aroids species.
\end{abstract}

KEYWORDS: Araceae, limestone, pyroclastics, diversity, abundance, topography, geography

\section{Introduction}

Araceae Juss. is a family of perennial evergreen to seasonally dormant monocotyledonous herbs defined at the macromorphological level by an inflorescence consisting of a spike of small bractless flowers on a fleshy unbranched axis (spadix) subtended by a bract or modified leaf (spathe) (Yeng, 2009). Well-known as a diverse family of monocotyledon and the third largest monocotyledon family after orchids and grasses and seventh largest of all flowering plants after Asteraceae, Fabaceae, Rubiaceae, and Lamiaceae (Mayo et al., 1997). It comprises of approximately 121 genera and probably as many as 6000 species around the world. In Peninsular Malaysia there are about 23 genera with 123 species which have been recorded (Sulaiman and Mansor, 2001). Most aroids are tropical and include members from terrestrial, aquatic, and epiphytic habitats although there are many aroids indigenous to temperate climates (Yeng, 2009). 


\section{Assessment on Diversity and Abundance of Araceae in Limestone and Pyroclastics Areas in Gua Musang, Kelantan, Malaysia}

Vegetatively, the aroids range in size from minute to gigantic, and in habit from lianescent or subshrubby hemiepiphytes, to epiphytes, lithophytes, terrestrial mesophytes, geophytes, rheophytes, sometimes helophytes, and true or free-floating aquatics (Ridley, 1925). They are predominantly tropical in distribution, with $90 \%$ of the 110 currently recognized genera and c. $95 \%$ of c. $4000+$ species restricted to the everwet or perhumid tropics (Bown, 1988). Ecologically they are a very important herbaceous family in terms of their dominance of the understorey and inter canopy herb layer and as indicators of forest quality. Aroids are most abundant and diverse in undisturbed perhumid habitats (Jenny, 1941).

Although Araceae are still poorly known in most Neotropical countries, numerous inventories in humid tropical forests show high aroid richness and often list Araceae among the 10 most species rich families of vascular plants. Furthermore, numerous studies on their ecologies and diversity were done to understand the biology of aroids (Ana-Maria et al., 2005; Croat, 2004; Jenny, 1941; Knab-Vispo et al., 2003; Leimbeck et al., 2004; Mayo et al., 1997; Miyasaka et al., 2003; Plowden et al., 2003).

To date, no extensive studies on diversity and abundance of Araceae had been related to geological and geographical features in Kelantan state, Peninsular Malaysia. The state's rich and lavish varieties of geological types and derived soils are remained unexplored for the suitability of plant growth. Many enigmatic species of aroids such as species from Homalomena and Aglaonema genus are poorly studied in term of their locality and endemism and their diversity comparison from different substrates. However, the bold increase in our geological and botanical knowledge since the days of the early plant geographers has widened our horizon and enlarged our retrospect (Just, 1947).

\section{Materials and method}

\section{Study Site}

Study sites Kuala Koh Wildlife and National Park Protection (PERHILITAN) (N 04 52' 02.2”/ E $102^{\circ} 26^{\prime}$ '33.3") at Kuala Koh, Gua Musang, Kelantan and an area nearby Pusat Konservasi Hidupan Liar (PKHL PERHILITAN) (N 04 46' 11.9”/ E 101 58' 35.5”) at Tanah Puteh, Gua Musang, Kelantan. Kuala Koh National Park, Kelantan is under the authority of PERHILITAN (Wildlife and National Park Protection) Malaysia agency and become a section of Taman Negara, Malaysia's premier national park which straddles across Kelantan and two other neighbouring states; Terengganu and Pahang. Taman Negara is one of the oldest rainforests in the world, estimated to be 130 million years old. In addition, the area is very well-known for its high species diversity of flora and fauna due to its complex and rich ecosystem in the world. Spread over $1,043 \mathrm{sq} \mathrm{km}$, this dense undisturbed jungle is home to various flora and fauna (Ministry of Tourism, 2009). All of the data collections were conducted from February 2011 until April 2011.

\section{Sampling Procedures}

Aroid samples were collected from the study sites. The relative abundance of aroids was obtained by setting up a plot of 1 hectare (ha) width within the study area. Aroid plants were surveyed in 1 ha major plot divided into 100 equal $10 \mathrm{~m} \times 10 \mathrm{~m}$ plots located through stratified random sampling. The information such as their latitude and longitude of the sampling site and the number of aroids in each was collected. Width (A) calculation of a square plot as below: 
Assessment on Diversity and Abundance of Araceae in Limestone and Pyroclastics Areas in Gua Musang,

Kelantan, Malaysia

Width $(\mathrm{A})=1$ ha

1 hectare (ha) $=100 \mathrm{~m} \times 100 \mathrm{~m}$

$=10,000 \mathrm{~m}^{2}$

While sampling in each plot, aroid samples were identified and counted for individual species number as species abundances per 1-ha plots. Aroids collected for each species need to be done for at least three replicates. For each different species of aroids found in the plots, we divided into two aroid trees to be recultivated ex-situ at the conservatory area in UMK Agro Park, Pengkalan Chepa, Kelantan and the last tree to be made as herbarium specimen for the species identification and further references in the future.

\section{Herbarium Specimen Preparation}

All of aroid samples collected were pressed using square wooden press (1m x $1 \mathrm{~m}$ in size) before being dried. After pressing, pressed aroid samples were dried in an oven (Leica 560 Oven) for a week in $50^{\circ} \mathrm{C}$. After drying process, the samples were placed on the $\mathrm{A} 3$-sized herbarium sheet covered with plastics and systematic tags containing the details of samples such as collector's name, places of collection, date of collection, species name, and habitat were adhered on the herbarium sheets.

\section{Identification of Aroid Samples}

Specimen identification was done at the Herbarium Laboratory, Faculty of Biological Sciences, Universiti Sains Malaysia, Penang. Furthermore, identification of the specimens were done using keys provided by Bown (1988), Boyce, (1998), Boyce, (1999), Hay, (1998a, 1998b), Mayo et al. (1997) and Ridley (1925).

\section{Results and discussion}

\section{Diversity and Abundance of Aroids in Tanah Puteh}

A total of 5900 free-standing and climbing aroids represents 28 species from 11 genera were recorded in 1 hectare plot at Tanah Puteh, Gua Musang (Table 1). Among 11 genera of aroids noted in Tanah Puteh, the most diverse genus was Homelomena with 10 species. The least diverse genera were Pothos, Aglaonema, Alocasia, Amorphophallus, Colocasia and Epipremnum with only one species for each. The genus of Anadendrum, which was represented by three species, was considerably more abundant than any other species of aroids. Anadendrum microstachyum is the most abundant aroids in Tanah Puteh (Figure 1). Its juveniles and adults were noted in every subplot of $10 \mathrm{~m} \times 10 \mathrm{~m}$. A. microstachyum represents a total of 1441 individuals with relative density of $24.4 \%$. It was followed by Homalomena griffithii with 760 individuals (12.9\%) and hemiepiphytic Rhaphidophora tenuis with 678 individuals (11.5\%). 
Assessment on Diversity and Abundance of Araceae in Limestone and Pyroclastics Areas in Gua Musang, Kelantan, Malaysia

\begin{tabular}{|c|c|c|}
\hline Species & $\begin{array}{l}\text { Number of } \\
\text { aroids }\left(\mathrm{ha}^{-1}\right)\end{array}$ & $\begin{array}{c}\text { Relative density } \\
(\%)\end{array}$ \\
\hline Anadendrum microstachyum & 1441 & 24.4 \\
\hline Homalomena griffithii & 760 & 12.9 \\
\hline Rhaphidophora tenuis & 678 & 11.5 \\
\hline Schismatoglottis brevicuspis & 557 & 9.4 \\
\hline Anadendrum angustifolium & 486 & 8.2 \\
\hline Scindapsus perakensis & 385 & 6.5 \\
\hline Rhaphidophora maingayi & 266 & 4.5 \\
\hline Homalomena wallichii & 264 & 4.5 \\
\hline Schismatoglottis calyptrata & 236 & 4 \\
\hline Aglaonema nitidum & 188 & 3.2 \\
\hline $\begin{array}{l}\text { Homalomena new related to } \\
\text { H. giamensis }\end{array}$ & 156 & 2.6 \\
\hline Homalomena curvata c.f. & 120 & 2 \\
\hline Schismatoglottis wallichii & 86 & 1.5 \\
\hline Homalomena pontederiifolia & 56 & 0.9 \\
\hline Homalomena truncata & 47 & 0.8 \\
\hline Homalomena in Hanneae complex & 43 & 0.7 \\
\hline Pothos scandens & 27 & 0.5 \\
\hline Anadendrum marginatum & 23 & 0.4 \\
\hline Rhaphidophora falcata & 17 & 0.3 \\
\hline Scindapsus hederaceus & 17 & 0.3 \\
\hline Scindapsus treubii & 16 & 0.3 \\
\hline Alocasa longiloba & 9 & 0.2 \\
\hline Colocasia gigantea & 5 & 0.08 \\
\hline Epipremnum giganteum & 5 & 0.08 \\
\hline $\begin{array}{l}\text { Homalomena in Chamaecladon } \\
\text { (H. humilis) }\end{array}$ & 4 & 0.07 \\
\hline $\begin{array}{l}\text { Homalomena in Chamaecladon } \\
\text { (H. pumila) }\end{array}$ & 4 & 0.07 \\
\hline $\begin{array}{l}\text { Homalomena in Chamaecladon } \\
\text { (H. angustifolia) }\end{array}$ & 3 & 0.05 \\
\hline Amorphophallus sp. & 1 & 0.02 \\
\hline
\end{tabular}

Table 1: List of species and relative density of aroids in Tanah Puteh, Gua Musang, Kelantan. 


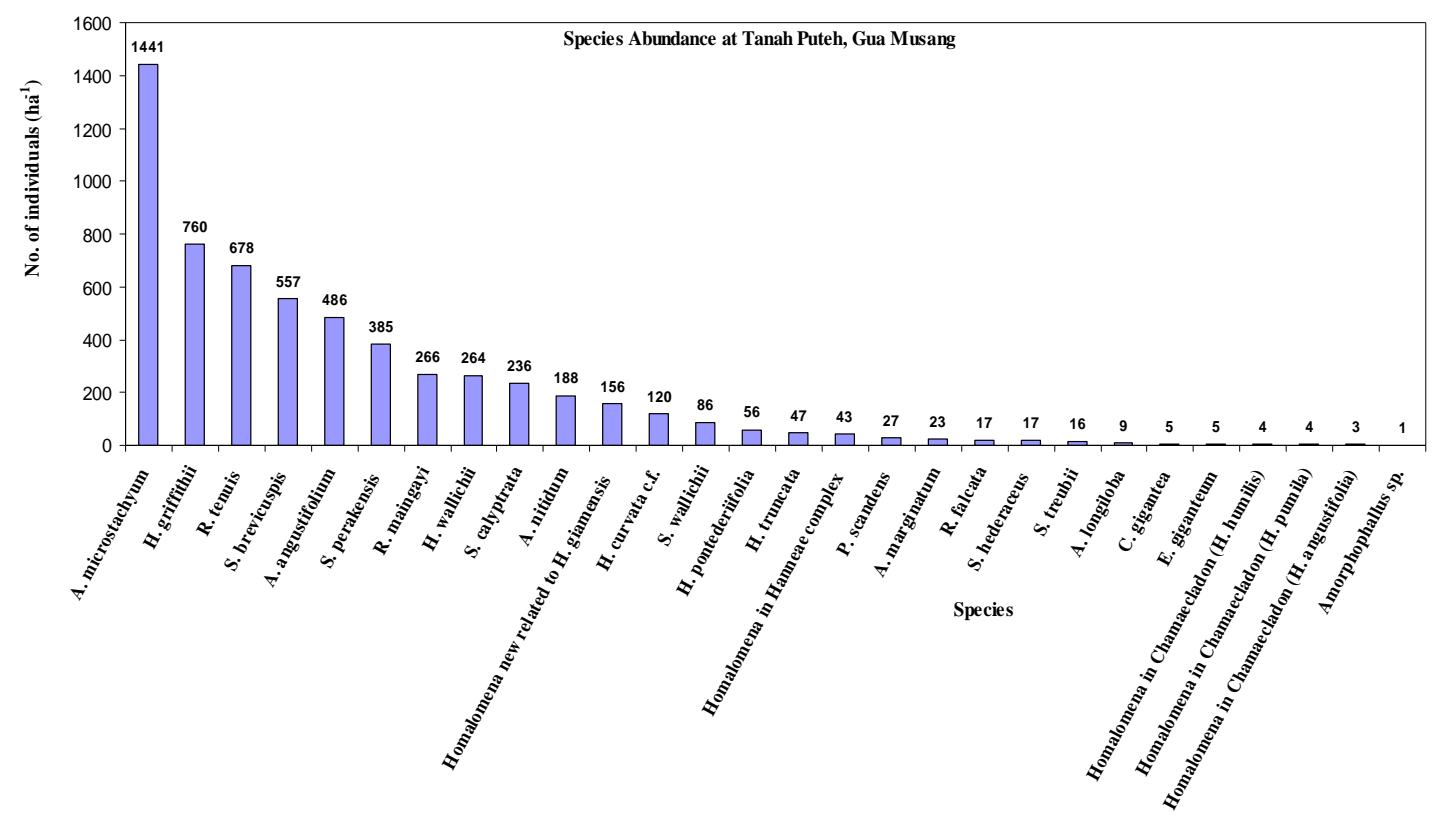

Figure 1: Species and abundance of aroids ha ${ }^{-1}$ in Tanah Puteh (limestone), Gua Musang, and Kelantan.

\section{Diversity and Abundance of Aroids in Kuala Koh}

Meanwhile, a total of 6404 individuals of aroids represents 21 species from seven genera were documented in Kuala Koh, Gua Musang (Table 2). Nevertheless, in Kuala Koh study site, the most diverse genus was corresponding with the one at Tanah Puteh, genus Homalomena which represented by 7 species (Table 2) and followed by Schismatoglottis $(\mathrm{n}=5)$ and Scindapsus $(\mathrm{n}=3)$. However, in Kuala Koh, Anadendrum was a single species genus counting on only Andendrum microstachyum species together with Alocasia genus which was represented by only Alocasia longiloba species. From the total number of individuals, two species had only one individual for the entire survey in the plot, which were Scindapsus perakensis $(0.02 \%)$ and Aglaonema simplex $(0.02 \%)$ and became rare species in Kuala Koh. Schismatoglottis was a promising genus that could thrive well in Kuala Koh ecosystems since its number of individuals a lot greater than any other genera found (Figure 2).

Noted that Schismatoglottis calyptrata became the most abundant species with the relative density of $32.2 \%$ (2060 individuals). They were transforming most of the small streams with static, shallow water and muddy conditions into its colonies. It was followed by $S$. brevicuspis which mostly infested small streams and $S$. scortechinii, which thrived at the edge of streams or inundated slope area. For the number of individuals, Schismatoglottis scortechini showed 1651 individuals and Schismatoglottis brevicuspis had 1066 individuals. For the relative density, Schismatoglottis genus provided more than a half of the density of aroids composition in Kuala Koh which outnumbered other genera with $74.6 \%$. 
Assessment on Diversity and Abundance of Araceae in Limestone and Pyroclastics Areas in Gua Musang,
Kelantan, Malaysia

\begin{tabular}{lcc}
\hline Species & $\begin{array}{c}\text { No. of aroids } \\
\left(\mathrm{ha}^{-1}\right)\end{array}$ & $\begin{array}{c}\text { Relative density } \\
(\%)\end{array}$ \\
\hline Schismatoglottis calyptrata & 2060 & 32.2 \\
Schismatoglottis scortechinii & 1651 & 25.8 \\
Schismatoglottis brevicuspis & 1066 & 16.6 \\
Anadendrum microstachyum & 349 & 5.5 \\
Aglaonema nitidum & 289 & 4.5 \\
Rhaphidophora mangayi & 285 & 4.5 \\
Rhaphidophora korthalsii & 168 & 2.6 \\
Schismatoglottis wallichii & 113 & 1.8 \\
Homalomena truncata & 86 & 1.3 \\
Scindapsus spl & 76 & 1.2 \\
Homalomena griffithii & 75 & 1.2 \\
Scindapsus scortechinii & 61 & 1 \\
Homalomena wallichii & 54 & 0.8 \\
Homalomena curvata & 29 & 0.5 \\
Alocasia longiloba & 22 & 0.3 \\
Scindapsus treubii & 11 & 0.2 \\
Homalomena in Chamaecladon & 3 & 0.05 \\
Homalomena in Cyrtocladon & 2 & 0.03 \\
Homalomena pontederiifolia & 2 & 0.03 \\
Aglaonema simplex & 1 & 0.02 \\
Scindapsus perakensis & 1 & 0.02 \\
\hline
\end{tabular}

Table 2: Complete list of aroids, identified over 1 ha plot, including the number of aroids and their relative density in Kuala Koh (pyroclastics area), Gua Musang, Kelantan. 


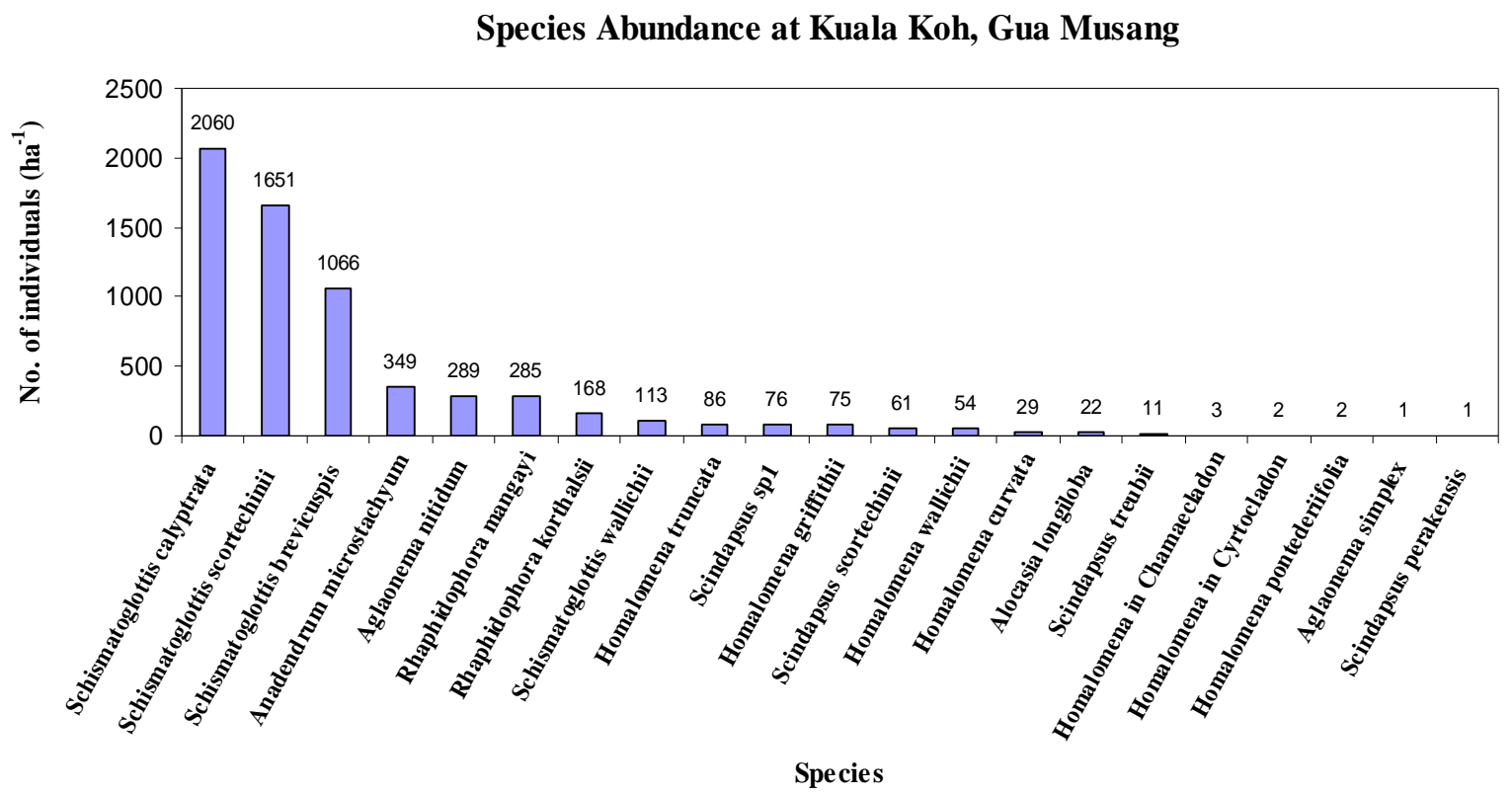

Figure 2: Species and abundance of aroids $\mathrm{ha}^{-1}$ in Kuala Koh (pyroclastics), Gua Musang, and Kelantan.

In Tanah Puteh, most of aroids were found at an altitude between 100-200m a.s.1. However, the altitude in Kuala Koh is generally below than $100 \mathrm{~m}$. According to Leimbeck et al. (2004), in their study in Ecuador the diversity of aroids is slightly higher at lower altitude. They found Araceae species richness is highest between sea level and $1500 \mathrm{~m}$ and there is a steady decrease in diversity with increasing altitude. Another study done by Bown, (1988) stressed that species richness is greatest between sea level and middle elevations to about 1500 meters. However, diversity drops off dramatically above $2000 \mathrm{~m}$ except for certain species that can survive in higher altitude up to $3750 \mathrm{~m}$.

For the species comparison between two areas, Amorphophallus was not found in Kuala Koh area and existed in Tanah Puteh even in sparse number. Another species comparison was Pothos genus. Pothos species were pretty great in numbers in Tanah Puteh and became the most dominant species on most limestone walls. Yet in Kuala Koh, there is hardly any single species is noted. This is due to the differences in geomorphological of the locations. Researchers found not all habitat types are equally suitable to support dense Araceae populations (Knab-Vispo et al., 2003) and soils (weathered products of rocks) which reflect quality of parent material, both in physical properties and chemical content select certain species from a region's available flora to grow (Kruckeberg, 2002). With this fact, it gives species difference in Kuala Koh and Tanah Puteh in term of their richness.

In both areas of study, common epiphytic aroid species were Anadendrum microstachyum and Rhaphidophora maingayi. From this, we can conclude that the common category of aroid species in both sites was epiphytic aroids. This circumstance may be elaborated 


\section{Assessment on Diversity and Abundance of Araceae in Limestone and Pyroclastics Areas in Gua Musang, \\ Kelantan, Malaysia}

by (Ana-Maria et al., 2005), which found two genera of epiphytic Araceae also, Philodendron and Anthurium, in quantitative census of vascular epiphytes of Colombian Amazon. In addition, Philodendron and Anthurium had the highest species richness in studying epiphytes ecologies. Further studies of epiphytes aroids found that they are having a high dispersal ability, which would allow a more rapid colonization and should lead to a wide distribution of many epiphyte species in all landscapes (Ana-Maria et al., 2005).

\section{Conslusion}

In recent years, numerous studies had been done to increase our geological and botanical knowledge and their interactions. Yet, the information to understand specific Araceae family in relation to their geological features are lacking. This study increased our knowledge and understandings of aroid communities with their parent materials (geologically-derived substrates). Further studies of aroid and their relations with geomorphical characteristics are vital since geological factors are much more important causes of plant distribution and diversity patterns than others.

\section{Acknowledgments}

The authors would like to thank the Malaysian Ministry of Higher Education and Universiti Malaysia Kelantan for their financial support through Short Term Research Grant (SRGP).

\section{References}

Ana Maria, B. D., Alvaro, J. D. M., Duivenvoorden, J. F., Vasco, G. A., Callejas, R., (2005). A first quantitative census of vascular epiphytes in rain forests of Colombian Amazonia. Biodiversity and Conservation. 14, 739-758.

Bown, D., (1988). Aroids: Plants of the Arum Family. Century Pub., 256. Boyce, P. C., (1998). The genus Epipremnum Schott (Araceae - Monteroideae-Monstereae) in west and central Malesia. Blumea, 43(1), 183-213.

Boyce, P. C., (1999). The genus Rhaphidophora Hassk. (Araceae-Monteroideae-Monstereae) in Peninsular Malaysia and Singapore. Garden's Bulletin Singapore, 51, 183-256.

Croat, T. B., (2004). History and current status of systematic research with Araceae. Aroideana, 6, 26-145.

Hay, A., (1998a). A new species of Aglaonema Schott (Araceae) from Terengganu, Malaysia. Garden's Bulletin Singapore, 50, 1-4.

Hay, A., (1998b). The genus Alocasia (Araceae-Colocasieae) in West Malesia and Sulawesi. Garden's Bulletin Singapore, 50, 221-334.

Jenny, H., (1941). Factors of soils formations. New York, McGraw-Hill Inc., 190-234.

Just, T., (1947). Geology and plant distribution. Ecological Monographs, 17 (2), 127-137.

Knab-Vispo, C., Hoffman, B., Moermond, T., Vispo, C., (2003). Ecological observations on Heteropsis spp. (Araceae) in Southern Venezuela. Economic Botany, 57(3), 345-353. 
Kruckeberg, A. R., (2002). Geology and plant life: Effects of landforms and rock types on plants. University of Washington Press, 362.

Leimbeck, R. M., Valencia, R., Balslev, H., (2004). Landscape diversity patterns and endemism of Araceae in Ecuador. Biodiversity and Conservation, 13, 1755-1779.

Mayo, S.J., Bogner, J., Boyce, P.C., (1997). The genera of Araceae. CATE Araceae, 370.

Ministry of Tourism, (2009). Kelantan: cradle of Malay culture. Tourism Malaysia Brochure. Tourism Malaysia, Ministry of Tourism. 1-48.

Miyasaka, S. C., Ogoshi, R. M., Tsuji, G. Y., Kodani, L. S., (2003). Site and planting date effects on taro growth: comparison with aroid model predictions. Agronomy Journal, 95, 545557.

Plowden, C., Uhl, C., Oliveira, F. A., (2003). The ecology and harvest potential of titica vine roots (Heteropsis flexusa: Araceae) in the eastern Brazilian Amazon. Forest Ecology and Management, 182, 59-73.

Ridley, H. N., (1925). Order ClvШ. Aroideae. Flora of the Malay Peninsula., 5, 84-182.

Sulaiman, B.; Mansor, M., (2001). Utilization of aroids for medicinal purposes. In Prosiding Persidangan Kebangsaan P\&P IPTA, Pulau Pinang, Malaysia 25-27 May. University Sains Malaysia: Pulau Pinang.

Yeng, W. S. (2009). Phylogenetic and systematic studies of the Schismatoglottideae (Araceae: Aroideae). Ph.D. Dissertation, University Sains Malaysia. Malaysia. 